\title{
A tanulás sikerességének vizsgálata egészségügyi tanulmányokat folytató elsőéves hallgatók körében
}

\author{
Dinyáné Szabó Mariannal - Pusztai Gabriella dr. ${ }^{2}$ - Szemerszki Marianna dr. ${ }^{3}$ \\ ${ }^{1}$ Semmelweis Egyetem, Egészségtudományi Kar, Alapozó Egészségtudományi Intézet, Budapest \\ ${ }^{2}$ Debreceni Egyetem, Bölcsészettudományi Kar, Nevelés- és Múvelődéstudományi Intézet, Debrecen \\ ${ }^{3}$ Eszterházy Károly Egyetem, Oktatáskutató és Fejlesztő Intézet, Eger
}

Bevezetés: Az elsőéves hallgatók tanulmányi sikerességét - a preegyetemi tapasztalatokat is figyelembe véve - előre jelző összetevőket, jellemzőket találhatunk mind egyéni, mind infrastrukturális szinten, melyek mérhetők és felhasználhatók a tanulmányi eredményesség növeléséhez, és hozzájárulnak a hallgatói mentális egészség fenntartásához. Célkitüzés: Orvosi, fogorvosi, gyógyszerészi és egészégügyi szervezői tanulmányokat kezdő hallgatók körében, tanulmányi sikerességet előjelző jellemzők felkutatása.

Módszer: A Semmelweis Egyetem elsőéves hallgatói $(\mathrm{n}=550)$ körében kérdőíves adatgyüjtéssel kapott adatbázis elemzése. Logisztikus regresszióval határoztuk meg a hallgatói eredményességet befolyásoló szignifikáns magyarázó változókat.

Eredmények: Elkülönültek a különböző karok és presztízscsatornák eredményességet elősegítő tényezői és a hallgatói szükségletek, amelyek teljesülése egyben a hallgatói mentális egészség fenntartását is szolgálja. Két csoportot definiáltunk: (i) kartól független tényezők (például perzisztenciaérték, vallásos hit, WHO-jóllétérték, a sport fontossága, bizalom), (ii) karra jellemző tényezők (például ÁOK, FOK: szülői hatás a tanulásra, GYTK: a kapcsolatok fontossága nagy, EKK: a szülői végzettség meghatározó).

Következtetés: A hallgatói élet megkezdésekor mérésekkel felszínre kerülhetnek olyan tényezők, amelyek ismerete elősegítheti a későbbi sikeres tanulmányokat, megelőzve a lemorzsolódást. A tanulmányok alatt ezek a jellemzők folyamatosan monitorozhatók, így a hallgatói sikeresség érdekében a szükséges beavatkozások megtörténhetnek. Orv Hetil. 2020; 161(4): 139-150.

Kulcsszavak: tanulmányi sikeresség, társadalmi tőke, professzionalizáció, perzisztencia, jóllét, környezeti infrastruktúra

\section{Empirical study of learning success among first-year students in health education}

Introduction: Comprehensive predictors of first-year students' academic performance, including pre-university experience, can be found at both individual and infrastructural levels that can be measured and used to increase academic performance and contribute to student mental health.

Aim: To study the characteristics of students who are beginning their studies in medical, dental, pharmacy and health care organization.

Method: Analysis of a database obtained through questionnaire data among first-year Semmelweis University students $(\mathrm{n}=550)$. Significant explanatory variables influencing student performance were determined by logistic regression. Results: Different faculties and prestige channels have different success factors and student needs, the fulfillment of which also serves the maintenance of student mental health. Two groups were defined: (i) factors independent of age (perseverance value, religious belief, WHO value of well-being, importance of sport, trust), (ii) faculty-specific factors (Faculties of Medicine and Dentistry: parental influence on learning; Faculty of Pharmaceutical Sciences: the importance of relationships is high; Faculty of Health Sciences: parental qualifications are decisive).

Conclusion: At the start of a student's life, measurements can uncover factors that, if learned, can facilitate later successful studies, preventing early school leaving. During the course of studies, these features can be monitored continuously, so that the necessary interventions can be made to ensure student success.

Keywords: academic success, social capital, professionalization, perseverance, well-being, environmental infrastructure

Dinyáné Szabó M, Pusztai G, Szemerszki M. [Empirical study of learning success among first-year students in health education]. Orv Hetil. 2020; 161(4): 139-150.

(Beérkezett: 2019. augusztus 12.; elfogadva: 2019. szeptember 6.) 


\section{Rövidítések}

ÁOK = Általános Orvostudományi Kar; BSc = (bachelor of science) alapképzés; $\mathrm{df}=($ degree of freedom $)$ szabadságfok; EKK = Egészségügyi Közszolgálati Kar; FOK = Fogorvostudományi Kar; GYTK = Gyógyszerésztudományi Kar; MSc $=$ (master of science) mesterképzés; WBI-5 = (5-item WHO Well-Being Index) 5 tételes WHO Jóllét Kérdőív; WHO = (World Health Organization) Egészségügyi Világszervezet

A hallgatói jelentkezési szándék, a bejutás és a sikeres továbbhaladás a diplomaszerzésig egyéni utakat tükröz. Eltérő kulturális tőkével rendelkező családok gyerekei a különböző presztízsű intézményekbe, szakokra eltérô eséllyel jutnak be, és a hátrányos helyzetúek előtt bezáródó kapukat is lehet találni [1]. A bejutás már önmagában siker.

A felvételt nyert hallgatók körében az egyetemi világról alkotott elképzelés és a valóságról szerzett tapasztalatok között gyakran nagy a különbség, ami később gyenge tanulmányi teljesítményt, végül lemorzsolódást okozhat. A felsőfokú tanulmányok megkezdésekor mindez szorongást, a mentális egészség kezdeti romlását okozhatja a hallgatóknál. Az egyetemi oktatási szintre való áttérés legnagyobb nehézsége abban jelentkezik, hogy a hallgató itt már a saját tanulásáért felelős, ami nagyon nagy kihívás, és nem nélkülözheti az intézményi környezet odafigyelését [2].

A felsőoktatásba bekerült hallgató szocializációjának nagy kérdése, hogy intézményi befolyásként vagy hallgatói tapasztalatok hatására történő formálódásként kap-e értelmet. A hallgatói rekonstrukciós értelmezés a hallgatót mint szocializálandó „tárgyat” kezeli, az intézményi célok szigorú elfogadtatása után az intézmény beilleszti őt a hallgatók közé. A konstruktivista felfogás szerint a szocializáció során az újonc az intézmény és a szervezet tagjai közötti interakciók folyamatában szerzett tapasztalatok során fejlődik és érik hallgatóvá. A kapcsolathálózati strukturalista nézőpont azt feltételezi, hogy a „hallgató és az ô intézményen belüli és kívüli kapcsolathálójának közös aktivitása" adja a hallgatói társas környezet alakító tényezőit $[3,4]$. Az intézményi beillesztés esetén a hallgató „megtervezhető termék” [3]. Ha az intézmény (kar) odafigyel a hallgatók szükségleteire, és azokra megoldást is keres, akkor a hallgatói szocializáció a környezetre jellemző módon, hallgatói közremúködéssel - közös munka révén - nagyobb hallgatói eredményességet, tanulmányi sikerességet valószínúsítve jön létre, amiben a tudományterületi összekapcsolódások is segíthetnek $[5,6]$.

A felsőoktatás világába bekerült újoncok nagyobb része alkalmazkodik és halad előre, egy részük azonban az ismeretlen felé haladva, szorongva éli meg mindennapjait, küzd egy ideig, majd esetleg kihull az oktatásból. Ez kedvezőtlen a hallgató számára, de az oktatási szektor költségeinek megtérülése szempontjából is veszteség. A tanulás új paradigmája szerint a hallgatók aktivizálása saját tanulmányaikban meg tudja gátolni a kiesést, mivel így a hallgatók intenzívebben és magasabb színvonalon képesek tanulni, mint amekkora a hátterük és korábbi tanulmányi pályafutásuk alapján feltételezhetố lenne. Természetesen nem zárhatók ki a képességbeli korlátok sem, de a felsőoktatás-pedagógia jelenlegi eszköztára mellett a képzés vélhetően még messze áll e korlát elérésétól, s az aktív tanulással a hallgatók bizonyos területen mutatkozó hiányosságai mellett számos olyan képességterület tárható fel, amelyen átlag fölötti eredményességet, tehetséget mutatnak [7].

A társas integrálódás tanulmányi aspektusát tekintve már a tanulmányok kezdetén megmutatkozik a hallgatói involváltság, vagyis hogy a hallgató akarja-e, képes-e befektetni a képességeit, idejét, energiáját a tanulmányi sikereibe vagy sem [8]. A hallgatói szocializációt tanulási és nevelési folyamatnak tekintve, az oktatói szerepfelfogás bővítését megcélozva, az egyes intézmények (karok) felelőssége kerül előtérbe abban, hogy segítséget nyújtson - a szélesre tárt kapukon belépett - heterogén összetételú hallgatói társadalomnak, ezzel csökkentve a lemorzsolódás mértékét.

A szakirodalom egybehangzóan fontosnak tartja a hallgatói sikeresség, a tanulmányi eredményesség összefüggéseinek kutatását, ami elengedhetetlenül szükséges a hatékony intézményi beavatkozások megtervezéséhez [9]. A hallgatói sikeresség legelterjedtebb indikátora a tanulmányok törésmentes elvégzése, aminek magyarázatát a nemzetközi szakirodalom már három évtizede, a magyar felsőoktatás-kutatás pedig az utóbbi néhány évben kutatja, és bizonyítja a probléma fontosságát. A tanulmányok egyik vonulata intézményi perspektívából szemléli a jelenséget, és a hallgatói kudarc költségeire, illetve az intézményi fenntarthatóság instabilitására hívja fel a figyelmet. Az intézményi megközelítésben az okok között gyakran szerepel a beiratkozó hallgatók alacsony szintű általános felkészültsége és a várakozástól elmaradó képességszintje; viszonylag ritka, de előfordul olyan intézményi önkritika is, mint az erre adott reakcióként megjelenő, túlegyszerüsített, nagyüzemi oktatási és számonkérési módszerek megjelölése. A hallgató első éve létfontosságú az alapismeretek, a pozitív attitűdök, az önbizalom és az elkötelezettség megteremtésében, ezek alapozzák meg eredményességét, és erôsítik bennmaradási hajlandóságát. Ennek érdekében már az első évfolyamon meg kell határozni azokat a tényezóket, amelyek az egészségtudományi vagy bármely területen tanulók későbbi tanulmányi eredményességét befolyásolhatják. Az ilyen vizsgálatok segíthetnek az intézménynek a hatékonyabb hallgatói támogatás nyújtásában, a hallgatói eredményesség és bennmaradás előmozdításában [1012]. Első́ves ausztráliai egészségtudományi hallgatók tanulmányi eredményességét a szociodemográfiai jellemzők (női nem, nem őshonos státusz) és a korábbi tanulmányi jellemzók (a középiskola fenntartója, nyelvi kompetenciák, érettségipontszám) kontrollja alatt leginkább a belépéskori pontszám, a képzésben maradásukat pedig 
az egyetemi mentorprogramban való részvétel támogatta, amit az elsőéves vizsgajegyek is visszaigazoltak [13]. A Bécsi Orvostudományi Egyetem kutatói három tényezőt azonosítottak a tanulmányi eredményesség előrejelzésében: a férfinem, a nyelvi kompetenciák és a jó középiskolai teljesítmény. Eredményeik megerôsítik a középiskolai tanulmányok fontosságát, de a kutatók is jelzik, hogy ez nem lehet az egyetemi felvétel egyetlen kritériuma [14].

\section{Egyéni jellemzők}

$\mathrm{Az}$ eredményes hallgatói tanulmányi út jellemzőinek kutatása során esősorban a hallgató társadalmi, gazdasági báttere, a kulturális jellemzők, a vallásosság, az intézményi kontextus és a hallgatók kapcsolatai után szoktak érdeklődni a kutatók. A családból származó társadalmi tőke, a baráti, társadalmi kapcsolatok, a vallási, önkéntes tagságok mint sikert előre jelző mutatók szerepelnek a kutatásokban [4].

Coleman koncepciója volt szinte az első, amely szerint a tanulói teljesítményt a családi háttér nagy mértékben meghatározza [15]. A hallgatónak a választott intézményhez való tartozását a beágyazódásának mértéke mint egyéni jellemző - jeleníti meg. Az eredményes tanuláshoz a hallgató egyéni jellemzőinek egész sora szükséges: tudás, kíváncsiság, érdeklődés, de kell hozzá testi-lelki egészség, jövő- és munkaelképzelés [16]. A felsőoktatásba frissen belépő hallgatótól elvárható a morális tudatosság egyfajta magasabb szintje. A tanulmányi eredményességnek vannak objektív mutatói, de a szubjektív mutatókat közvetlenül a hallgatók tudják közvetíteni. Ilyen lehet a kitüzött diplomaszerzési cél, a választott intézmény melletti kitartás [10]. Kulcsfontosságú tényező a diákok erőfeszítése (involváltsága), kitartása (perzisztencia), amelyek felerősödnek az oktatási szint váltásakor, a kezdeti időben $[17,18]$. A tanulók kitartása, elköteleződése nem csupán fontos eredményességi tényezőnek tekinthető, hanem egyben kritikus feltételnek is a tanulmányi eredményesség szempontjából [17]. Az önhatékonyság fontos előrejelzője az akadémiai teljesítménynek [18]. Az önbecsülés - a hit abban, hogy amit megkezdett, végig is csinálja - nagy mértékben emeli az eredményesség szintjét. A munkavégzéssel kapcsolatos attitűdök, motivációk, a sport fontossága, a barátok megléte, a társas tapasztalatok (internetes kapcsolatok is) a mentális egészség fenntartásához, erősítéséhez járulnak hozzá [19], amire nagy szükség van a tanulmányok során. A hallgatói jóllétérzés (well-being) magas szintje, az eredményesség, a sikeresség a hallgatói aspiráció támogatói $[20,21]$.

Noha a „hatalom mások felett” jobbára a hallgatói értékhierarchia legvégén foglal helyet, egészségügyi pályán a hatalommal való élés is a szocializáció egyik területe $[22,23]$. Az autoritás negatív vonatkozásban (elnyomás, félelem stb.) gyakrabban kerül az emberekkel kapcsolatba, mint pozitív vonatkozásban (védelem, tájékoztatás, biztonság, bizalom, tisztelet stb.). A hallgatók azokkal az autoritásokkal azonosulnak, akikkel találkoznak. Az orvostanhallgatókat már szocializációjuk kezdetén érett autoritású oktatók veszik körül, tehát velük azonosulhatnak, náluk ez az érték a rangsorban elöl található. A hatalom forrása lehet a szakértelem, amely felfogható úgy is, mint az érvényesüléshez szükséges elem [24], felelősségvállalás, a személyes alkalmasság feltételezése, de a másokon való segítés eszköze is válhat belőle. A segítő foglalkozású emberek (orvosok, gyógyszerészek) esetében a másokon való segíteni akarás, az altruizmus kérdésköre egyértelmúen elvezet a segítői felelősség fogalmához, amely hivatástudatként is megjelenik. A segítő helyzet fölényt, hatalmat ad a segítő kezébe, valamint a segítés küldetéstudatként is megjelenhet - vallási keretbe helyezve - a hit részeként. A vallás fontossága, mint pozitív értékképző lehetőség, a magasan kvalifikált fiatalok erősödő jellemzőjeként jelentkezik [25-27]. A vallás komoly szerepet játszik a segítő identitás kialakulásában, a vallási közösséghez tartozók inkább hajlanak az altruista munkafelfogásra [26]. A vallásosság olyan értékeket, normákat, magatartásmintákat és közösségértelmezéseket alakít ki, amelyek egyértelmúen a hallgatói többletteljesítmény irányába hatnak. Olyan, intézményen kívülre nyúló kapcsolatháló, amelyből ösztönzőerő profitálható, amely a felsőoktatási előmenetelhez nyújthat támogatást $[5,28]$. A segítóktől elvárt az is, hogy személyes értékrendjüket vállalják.

A Cuseo-féle modell szerint a hallgatói eredményességben az értékpercepció (Tinto, 1987), az énhatékonyság (Bandura, 1977), az értelem megtalálása a tanulásban (Levitz és Noel, 1989), az aktív részvétel (Astin, 1984, Pascarella-Terenzini, 1991), a társadalmi integráció (Astin, 1993), a személyes reflexió (Ewell, 1997), az önismeret, a metakogníció (Weinstein és Underword, 1985 ) játszik szerepet (idézi [29]). Az a hallgató lesz eredményes, aki elvárt szintű morális értékrenddel, énhatékonyságának tudatában célt-értelmet talál a tanulásában közösségi aktív részvétellel, ezáltal megfelelő mértékben integrálódik a közösségébe, saját véleményt képes kialakítani, gondolkodásán elgondolkodva, magas fokú fejlődőképességről tesz tanúbizonyságot.

\section{Az intézményi (kari) környezet jellemzői}

Az egyéni jellemzók mellett a hallgatói környezet is a hallgatói sikeresség fontos előrejelzője [11]. Coleman társadalmitőke-elméletében kifejti, hogy az intézménystruktúra, a benne közvetített információk, értékek, tartalmak, a kapcsolati struktúrához való kötődés nagy húzóerőt jelent az egyén céljainak megvalósításához [30]. Az elmélet nevelésszociológiai jelentősége azért is nagy, mert megerősíti, hogy egy oktatási intézmény az ottani szereplők közös cselekvési tere, közös lehetőségei és közös felelőssége. A felsőoktatásra alkalmazva: az intézmények (karok) által biztosított környezetben élő hallgatók tudományterületi, kapcsolati és saját hagyományaik által 
meghatározott kultúrában léteznek, amelyben az elvárt/ hozott értékek, normák találkoznak, és a közös részvételben csiszolódnak. Ez a kultúra hat a hallgatói eredményességre, felhasználható a hallgatói társadalmi tőke mértékére, illetve az intézmény eredményes múködésére. A felsőoktatási szereplők közötti bizalom, az oktatói interakciók, az egyetemi társak barátsága a hallgatói beágyazódást segítve kikövezik a hallgatói siker útját egészen a diploma megszerzéséig vagy azon is túl.

A hallgatói siker szempontjait vizsgáló Kub-féle modell a hallgatói környezetet is figyelembe véve öt változócsoportot különít el:

1. a hallgatói háttér jellemzői (demográfiai adatok, egyetem előtti tapasztalatok),

2. az intézmények strukturális jellemzői (misszió, méret, szelektivitás),

3. együttmúködés az oktatókkal és más munkatársakkal, valamint társakkal,

4. a tanulási környezettel kapcsolatos hallgatói nézetek,

5. az oktatási tevékenységekre fordított tanulói erőfeszítések [31].

Az intézményi környezetnek a statisztikai adatokkal, az intézményi tulajdonságok előtérbe helyezésével való mérései azt sugallják, hogy a legjobb esetben arra kaphatunk választ, hogy a hallgatók mekkora hányadának sikerül az intézmény szerint elvárt, ideális hallgatóvá válás. A hallgatói eredményesség, sikeresség értelmezésében a hallgatói perspektíva is helyet kell, hogy kapjon, melynek segítségével árnyaltan jeleníthetők meg a jelenség tartalmi, kvalitatív jellemzői, ezért vizsgálatunkban is hallgatói adatokra támaszkodunk.

\section{A kutatás célja}

Vizsgálatunk a hallgatói tanulmányi eredményességet befolyásoló jellemzők felkutatását tűzte ki célul, egészségügyi tanulmányokat kezdő, elsőéves hallgatók körében. Egyéni szinten mérhető teljesítményjellemzőket és intézményi környezeti jellemzőket (hallgatói infrastruktúrahasználati szokásokként) vizsgáltunk. Előző vizsgálatainkban részletesen foglalkoztunk a hallgatói jólléttel (az 5 tételes WHO Jóllét Kérdőív alapján [21]), a hallgatói perzisztencia (kitartás) kérdésével és a sport fontosságával a hallgatók körében [18]. Ezeket az adatokat felhasználtuk mostani elemzésünkben.

A vizsgálatban részt vevő orvostanhallgatók (általános és fogorvos) - gyógyszerészek képzése „közös tőről” fakad, ugyanannak az ügynek a két oldalán állnak. Az egészségügyi szervező szakosok (BSc) informatikai tudásukat az egészségügy szolgálatába állítva - a Semmelweis Egyetem és a Múszaki Egyetem oktatói által képezve egy új dimenzióval gazdagítják ezt a kört. Az oktatás különböző presztízscsatornáit múködtető intézmények (karok) közös prioritása hallgatóik eredményes szakmai szocializációjának előkészítése.
Tanulmányunk a Pusztai-féle eredményességi modell segítségével próbálta feltárni, hogy milyen tényezők hatnak a frissen belépett hallgatók eredményes tanulására. A modell alkalmazása során a következő hallgatói jellemzőkre derülhet fény:

1. belépett a felsőoktatás általa kiválasztott szegmensébe,

2. tanulmányi folytonosság tapasztalható,

3. tanulmányok iránti elköteleződést mutat (a tanulásban való elszánt, értékorientált részvétel, tanulmányi erófeszítés),

4. az akadémiai normák elfogadója (a diplomás ember magatartásmintájának prediktora),

5. tanulmányi céljai mellett kitart,

6. munkavállalási és későbbi továbbtanulási hajlandóság jellemzi [3].

A hallgatói eredményességre ható intézményi környezet vizsgálatában egyrészt a Strange-féle koncepció négy dimenzióját [32] vettük alapul: 1) fizikai: egyetemi könyvtár, menza, kollégium, sport; 2 ) kompozíció: nem, életkor, társadalmi státusz; 3 ) szervezeti jellemző: bizalom; 4) kultúrajellemző: hallgatói munkamorál. A hallgatók szubjektív véleménye tükröződik a kérdőívre adott válaszaikban. A hallgatói relációk vizsgálatához a Pusztai-féle felsőoktatási kapcsolathálózati beágyazódás kérdésblokkjára támaszkodtunk [5].

\section{Módszer}

\section{Minta}

A felmérés a Semmelweis Egyetem elsőéves hallgatóinak körében történt, kérdőíves adatgyüjtéssel (ÁOK = 90 fö, $\mathrm{FOK}=175$ fö, GYTK = 145 fö, $\mathrm{EKK}=140$ fö BSc egészségügyi szervező szakos hallgató), összesen 550 fövel. Az adatfelvétel 2014 és 2016 között történt online kérdőíves felméréssel. A hallgatók a kérdőíveket önkéntes alapon töltötték ki. Részletesebb mintaszámok: ÁOK = 90 fö (32 férfi és 58 nő) 17\%; FOK = 175 fö (64 férfi és 111 nő) $32 \%$; GYTK = 145 (38 férfi és 107 nő) $25 \%$; $E K K=140$ fő (22 férfi és 118 nő) $26 \%$. A kérdőív változóiból aggregált változókat képeztünk vizsgálati modelljeink számára.

\section{Statisztikai analizis}

A folytonos változók értékeire leíró statisztikai módszert használtunk. A karok közötti összehasonlításra robusztus Welch-ANOVA-módszert, illetve független kétmintás $t$-tesztet alkalmaztunk. Kategorikus változók esetén khi-négyzet-tesztet használtunk a változók közötti függetlenség vizsgálatára, az oszlopszázalékos értékeket Bonferroninek a korrigált p-értékek kiszámítására vonatkozó módszerével értékeltük. A dichotóm 'Sikerességi index' (magyarázott változó) és a prediktor változók (független magyarázó változók) közötti hatás vizsgálatára - annak meghatározására, hogy mely változók vannak 
hatással a hallgatók tanulmányi eredményességére, sikerességére - bináris logisztikus módszert alkalmaztunk a szignifikáns magyarázó változók szűrésére. Szignifikáns eredménynek a $\mathrm{p}<0,05$ értéket tekintettük. Az elemzéseket az SPSS Statistics 25.0 programcsomaggal (IBM Corporation, Armonk, NY, Amerikai Egyesült Államok) végeztük.

\section{a) Vizsgált függő változó}

A 'Sikerességi index' képzése

Első lépésben négy aggregált változói alcsoportot képeztünk a kérdőív meghatározott kérdései alapján: összeadtuk az egyes kérdésekre adott válaszok értékeit:

1. intézményi tudásszerzés: a saját tanulásba fektetett hallgatói erőfeszítések,

2. tanulmányi normák: a diplomás ember magatartásának mintája,

3. munkavállalási hajlandóság: önkéntes, fizetett munka iránti,

4. későbbi továbbtanulás: önképzési hajlandóság.

A négy alcsoport összege képezi a folytonos eloszlású 'Sikerességi pontszámot', amelyből dichotóm 'Sikerességi index' változót képeztünk: a $\mathrm{Q}_{1} \leq 75 \%$ érték alatti pontszámösszeget elérő hallgató besorolása átlagos/ gyengébb, a $\mathrm{Q}_{2}>75 \%$ feletti pontszám esetén eredményesebb a hallgató besorolása.

\section{b) Független változók}

A logisztikus modellben vizsgált'Sikerességi index' fóbb prediktor változói:

a) Vizsgált folytonos változók: perzisztenciaérték [17], szerzett többletpontok, közösségi tagság, a sport fontossága, egyetemen belüli barát, egyetemen kívüli barát, szabadidő-eltöltés, akadémiai érték, internethasználat, önkéntesmunka-végzés, WHO-jóllét [20-21] stb.

b) Vizsgált kategorikus változók: a hallgatók neme, a szülők végzettsége, első helyen vették-e fel, fizetett különóra, vallásos hit, a látogatott órák százalékban kifejezett aránya, bizalom (interperszonális + intézményi bizalom), a szülők hatása a tanulásra, 'Intézményi környezeti index'.

\section{Az 'Intézményi környezeti index' képzése}

Két aggregált alcsoportot képeztünk a kérdőív meghatározott kérdései alapján: összeadtuk az egyes kérdésekre adott hallgatói válaszok pontértékeit:

1. Intézményi_tárgyi változó összetevői: könyvtárhasználat, egyetemi menza, a sport lehetősége, kollégiumi elhelyezés.

2. Intézményi_reláció változó összetevői: egyetemi barát, egyetemen kívüli barát, egyetemi oktatóval való kapcsolattartás.

Két aggregált változó összegeként határoztuk meg a folytonos eloszlású 'Intézményi környezeti' változót, amelyet dichotomizáltunk az SPSS Visual Binning moduljával: szerényebb infrastruktúra $<43,5$; gazdagabb infrastruktúra $\geq 43,5$ pontszámhatárok alapján.

\section{Eredmények}

\section{Kari összetétel}

A hallgatók férfi-nő életkori megoszlása homogén (férfiak: $20,4 \pm 1,9$ év; nők: $20,2 \pm 1,9$ év; $\mathrm{p}=0,344$ ), nincs szignifikáns eltérés életkoruk átlagértékei között (a teljes minta átlagéletkora: 20,3 \pm 1,9 év). A négy kar között szignifikáns az eltérés a nemek arányai között (khi-négyzet $=19,45, \mathrm{df}=3, \mathrm{p}<0,001)$. Az eltérés két kar (EKK és FOK) férfi-nő arányainak szignifikáns eltéréseiből adódik (1. táblázat). A szülők együttes végzettségét illetően szignifikáns eltérést kapunk (khi-négyzet $=49,853, \mathrm{df}=$ 6, p<0,001). Az ÁOK és a FOK hallgatóira jellemző, hogy a szülők magasabb arányban felsőfokú végzettséggel rendelkeznek, míg az EKK-hallgatók esetén az alapfokú szülői végzettség a jellemző. GYTK-s hallgatók esetén a végzettségek közötti arány kiegyenlített (2. táblázat).

\section{A 'Sikerességi változók' és karonkénti összehasonlitásuk}

A vizsgált 'Sikerességi változók' szignifikáns eltérést mutattak a karok között:

1. táblázat | Nemek szerinti eloszlás a karokon

\begin{tabular}{|c|c|c|c|c|c|c|c|c|c|}
\hline \multirow[b]{3}{*}{ Kar } & \multicolumn{9}{|c|}{$\mathrm{Nem}$} \\
\hline & \multicolumn{3}{|c|}{ Férfi } & \multicolumn{3}{|c|}{ Nó } & \multicolumn{3}{|c|}{ Összesen } \\
\hline & $\mathrm{N}$ & Sor\% & Oszlop\% & $\mathrm{N}$ & Sor\% & Oszlop\% & $\mathrm{N}$ & Sor\% & Oszlop\% \\
\hline ÁOK & 32 & 35,6 & 20,5 & 58 & 64,4 & 14,7 & 90 & 100 & 16,4 \\
\hline EKK & 22 & 15,7 & 14,1 & 118 & 84,3 & 29,9 & 140 & 100 & 25,5 \\
\hline FOK & 64 & 36,6 & 41,0 & 111 & 63,4 & 28,2 & 175 & 100 & 31,8 \\
\hline GYTK & 38 & 26,2 & 24,4 & 107 & 73,8 & 27,2 & 145 & 100 & 26,3 \\
\hline Összes & 156 & 28,4 & 100 & 394 & 71,6 & 100 & 550 & 100 & 100 \\
\hline
\end{tabular}

ÁOK = Általános Orvostudományi Kar; EKK = Egészségügyi Közszolgálati Kar; FOK = Fogorvostudományi Kar; GYTK = Gyógyszerésztudományi Kar 
2. táblázat |A szüloók együttes végzettsége (mindig a magasabb végzettség számít)

\begin{tabular}{|c|c|c|c|c|c|c|c|c|c|c|c|c|}
\hline \multirow[b]{3}{*}{ Kar } & \multicolumn{9}{|c|}{ A szülők együttes végzettsége (mindig a magasabb végzettség számít) } & \multirow{2}{*}{\multicolumn{3}{|c|}{ Összesen }} \\
\hline & \multicolumn{3}{|c|}{ Alap } & \multicolumn{3}{|c|}{ Közép } & \multicolumn{3}{|c|}{ Felső } & & & \\
\hline & $\mathrm{N}$ & Sor\% & Oszlop\% & $\mathrm{N}$ & Sor\% & Oszlop\% & $\mathrm{N}$ & Sor\% & Oszlop\% & $\mathrm{N}$ & Sor\% & Oszlop\% \\
\hline ÁOK & 3 & 3,3 & 8,8 & 8 & 8,9 & 7,0 & 79 & 87,8 & 19,7 & 90 & 100 & 16,4 \\
\hline EKK & 17 & 12,1 & 50,0 & 47 & 33,6 & 41,2 & 76 & 54,3 & 18,9 & 140 & 100 & 25,5 \\
\hline FOK & 5 & 2,9 & 14,7 & 22 & 12,6 & 19,3 & 148 & 84,6 & 36,8 & 175 & 100 & 31,8 \\
\hline GYTK & 9 & 6,2 & 26,5 & 37 & 25,5 & 32,5 & 99 & 68,3 & 24,6 & 145 & 100 & 26,3 \\
\hline Összesen & 34 & 6,2 & 100 & 114 & 20,7 & 100 & 402 & 73,1 & 100 & 550 & 100 & 100 \\
\hline
\end{tabular}

ÁOK = Általános Orvostudományi Kar; EKK = Egészségügyi Közszolgálati Kar; FOK = Fogorvostudományi Kar; GYTK = Gyógyszerésztudományi Kar

a) Intézményi tudásszerzés: az intézmény által biztosított tudásszerzési lehetőségekkel az ÁOK- és FOK-hallgatók jobban élnek, mint az EKK- és GYTK-hallgatók. Az ÁOK-FOK hallgatók között nincs szignifikáns eltérés.

b) Tanulmányi normák: annak elfogadása, hogy menynyire tartja követendőnek egy diplomás ember magatartásmintáját. A FOK-hallgatók inkább képviselik ezt a magatartásformát, a legkevésbé az ÁOK- és EKK-hallgatók.

c) Munkavállalás: a hajlandóság az EKK-hallgatók esetén a legmagasabb, a hallgatók jelentős része a tanulmányok mellett folyamatosan dolgozik. A többi karon is vállalnak munkát.

d) Későbbi továbbtanulás: a szándék az EKK-hallgatók esetén a legmagasabb értékü: ez a szak BSc-jellegú, ezért befejezése után érthető, hogy érdeklődnek az MScképzés iránt.

\section{A 'Sikerességi index' vizsgálata}

Szignifikáns a besorolás eredménye az órák látogatottsága szerint (khi-négyzet $=6,811, \mathrm{df}=1, \mathrm{p}=0,009$ ). $\mathrm{Mi}$ nél magasabb az órák látogatottsági aránya, annál eredményesebb lesz a hallgató $(24,2 \%$ szemben a $35,9 \%$-kal $)$, illetve fordítva is igaz az állítás $(75,8 \%$ szemben a $64,1 \%$ $\mathrm{kal})$.

Az internet használatával kapcsolatban szignifikáns különbség adódik a 'Sikerességi kategóriák' között (khinégyzet $=17,125, \mathrm{df}=3, \mathrm{p}=0,001)$ : akik naponta használják az internetet tananyagok letöltésére, azok eredményesebbek lesznek, a tanulmányi célú internethasználat ugyanis növeli tudásukat.

A település kapcsolatát megvizsgálva az eredményességgel, azt tapasztaltuk, hogy a nagyobb helyen lakó (megyeszékhely, főváros) és felsőfokú végzettséggel rendelkező szülők gyermekei eredményesebbek (khi-négyzet $=6,605, \mathrm{df}=2, \mathrm{p}=0,0368)$. A 'Szülők végzettsége' és 'Sikerességi index' változók között szignifikáns a kapcsolat (khi-négyzet $=6,605, \mathrm{df}=2, \mathrm{p}=0,0368)$. A nagyobb településről érkező és szülői felsőfokú végzettség- gel bíró hallgatók is eredményesebbek. A középfokú végzettségü szülők gyermekeinek eredményessége átlagos vagy gyengébb. A kisebb települések esetén nem találtunk szignifikáns kapcsolatot a hasonló kontingenciatáblák képzése során.

Megvizsgáltuk az 5 tételes WHO Jóllét Kérdőív adatainak aggregált összegét, a 'perzisztenciaérték' és a 'sport fontossága', a 'szülői hatás a tanulásra', az 'egyetemi társ, aki segít a tanulásban' változó értékeit:

Összehasonlítva a két csoport értékeit, szignifikáns eltérés adódik:

WHO: $\mathrm{t}=-3,498, \mathrm{df}=548, \mathrm{p}=0,001$, Hedges' $\mathrm{g}=0,319$;

Perzisztencia: $\quad \mathrm{t}=-4,870, \mathrm{df}=548, \mathrm{p}<0,001$, Hedges' $\mathrm{g}=0,368$;

Sport: $\quad \mathrm{t}=-4,009, \mathrm{df}=548, \mathrm{p}<0,001$, Hedges' $\mathrm{g}=0,363$;

Szülői hatás: $\quad \mathrm{t}=-2,812, \mathrm{df}=318,5, \mathrm{p}=0,005$, Hedges' g = 0,265;

Egyetemi társ: $\quad \mathrm{t}=-3,772, \mathrm{df}=320,9, \mathrm{p}<0,001$, Hedges' $g=0,359$.

Azok a hallgatók lesznek eredményesek, akiknek 'jóllétérzése' magas, hasonlóan a magas perzisztenciaértékkel rendelkezőkhöz és a sporttevékenységet aktívan végzőkhöz. Az eredményességet a szülői hatás is szignifikánsan befolyásolja: az elsőévesek tanulmányaira jó hatással van a szülői kontroll. Hasonlóan pozitív hatása van az egyetemi társnak, aki segít a tanulásban: azok a tanulók eredményesebbek, akiknek van ilyen kapcsolatuk.

\section{Hallgatói értékpreferenciák}

A hallgatói értékpreferencia egyik vezető értéke, a vallásos hit az eredményességben is megmutatkozik: azok a hallgatók, akik számára fontos a hit, eredményesebbek, míg akiknek nem fontos a hit, kevésbé tünnek eredményesnek (khi-négyzet $=4,677, \mathrm{df}=1, \mathrm{p}=0,031$ ).

Az eredményesség szempontjából a „Hatalom mások felett" értékválasztás is szignifikáns összefüggést mutat (khi-négyzet $=26,540, \mathrm{df}=1, \mathrm{p}<0,001)$. A hallgatótár- 
sadalomban is küzdenek a hallgatók a hatalomért, mert megbecsülést hoz számukra, a többiek elismerik óket. Karrierjüket is befolyásolhatja ez a törekvés. Az egészségügyi professziót, az orvosi hivatást választó hallgatók esetén a hatalom forrása a szakértelem.

\section{Az intézményi környezet vizsgálata}

A 'Sikerességi index' és 'Intézményi környezet' változók között szignifikáns a kapcsolat (khi-négyzet $=22,496, \mathrm{df}$ = 1, p<0,0001). Az „Átlagos/gyengébb” eredményességü hallgatókra a „Szerényebb”, míg az „Eredményesebb” hallgatókra a "Gazdagabb” infrastruktúra használata jellemző. Megvizsgálva a „Szülői végzettség” és "Intézményi környezet” változók közötti kapcsolatot, azt találtuk, hogy szignifikáns a kapcsolat (khi-négyzet = $11,939, \mathrm{df}=2, \mathrm{p}<0,003)$. A „Felsőfokú végzettségü” szülők gyermekeire a „Gazdagabb infrastruktúra” használata jellemző.

Az „Intézményi környezet” és „Kar” változók között szignifikáns a kapcsolat (khi-négyzet $=10,735, \mathrm{df}=3, \mathrm{p}$ = 0,013). Az „Átlagos/gyengébb” csoportban az ÁOK és az EKK között nincs szignifikáns eltérés, de a FOK és a GYTK viszonylatában szignifikáns az eltérés, vagyis a GYTK-hallgatók kevésbé használják az egyetemi infrastruktúrát. A „Gazdagabb” csoportban is a GYTK hallgatói használják a legkevésbé az egyetemi infrastruktúrát, a legjobban a FOK hallgatói élnek a lehetőséggel. A „Település” és az „Intézményi környezet” változók közötti szignifikáns kapcsolat (khi-négyzet $=6,474$, df $=$
2, $\mathrm{p}=0,0393$ ) azt mutatja, hogy a „Megyeszékhely, fováros", tehát a nagyobb helyről jövő hallgatók jobban kihasználják az intézményi környezetet.

\section{Szervezeti jellemzők}

Szervezeti jellemzőként a bizalom jelenlétét vizsgáltuk meg.

A „Bizalom emberekben” és „Hallgatói eredményesség" változók között szignifikáns a kapcsolat (khi-négyzet $=6,120, \mathrm{df}=1, \mathrm{p}=0,013)$. Az alacsony bizalomszinttel rendelkező hallgatók eredményessége is gyengébb, míg a magas bizalommal rendelkező hallgatók eredményesebbek. Az intézmény iránti bizalom az eredményességben is megmutatkozik, mert azok a hallgatók, akiknél ez a szempont fontos tényező, azok eredményesebbek, vagy fordítva, akiknek nem fontos az intézmény iránti elkötelezettség, eredménytelenebbek (khi-négyzet $=4,567, \mathrm{df}=1, \mathrm{p}=0,033$ ). A „Bizalom” és „Kar” változók között szignifikáns a kapcsolat (khinégyzet $=10,735, \mathrm{df}=3, \mathrm{p}=0,013)$. Az ÁOK esetén ez az érték szignifikánsan magas, míg az EKK esetén alacsony a bizalomérték.

\section{A 'Sikerességi index' bináris logisztikus regressziós vizsgálata}

A 'Sikerességi indexet' mint dichotóm változót értékeltük bináris logisztikus analízissel. Mivel az ÁOK- és FOK-hallgatók eredményei között nem volt szignifi-

3. táblázat |Az orvosi fakultás logisztikus regressziós eredménye

Az orvostanhallgatók (ÁOK-FOK) változói

\begin{tabular}{|c|c|c|c|c|c|c|}
\hline \multirow[t]{2}{*}{ Változók } & \multirow[t]{2}{*}{$\mathrm{B}$} & \multirow[t]{2}{*}{ S.E. } & \multirow[t]{2}{*}{ Sig. } & \multirow[t]{2}{*}{$\operatorname{Exp}(B)$} & \multicolumn{2}{|c|}{$95 \% \mathrm{CI}$ for $\operatorname{EXP}(\mathrm{B})$} \\
\hline & & & & & Lower & Upper \\
\hline Perzisztencia & 1,695 & 0,729 & $0,020 *$ & 5,449 & 1,305 & 22,749 \\
\hline Hatalom mások felett & 3,036 & 1,062 & $0,004^{*}$ & 20,831 & 2,598 & 167,038 \\
\hline Vallásos hit & 1,975 & 0,826 & $0,017^{*}$ & 7,205 & 1,429 & 36,341 \\
\hline $\begin{array}{l}\text { Internet: tantárggyal kapcsolatos anyagot tölt le közösségi } \\
\text { oldalakról naponta }\end{array}$ & 0,040 & 0,017 & $0,016^{*}$ & 1,041 & 1,007 & 1,075 \\
\hline Szülő hatása a tanulásra & 1,784 & 0,776 & 0,021 * & 5,956 & 1,303 & 27,237 \\
\hline A sport fontossága & 0,199 & 0,079 & 0,012 * & 1,220 & 1,044 & 1,424 \\
\hline Hány \%-án vesz részt az óráinak & 0,620 & 0,276 & $0,025^{*}$ & 1,859 & 1,083 & 3,191 \\
\hline WBI-5 & 0,271 & 0,081 & 0,001 * & 1,311 & 1,118 & 1,537 \\
\hline Van olyan egyetemi társa, aki tanulási problémákban segít & 1,130 & 0,488 & 0,021 * & 3,097 & 1,189 & 8,063 \\
\hline Bizalom & 0,740 & 0,374 & $0,048^{*}$ & 2,097 & 1,010 & 4,366 \\
\hline Tárgyi dimenzió & 0,174 & 0,080 & 0,030 * & 1,190 & 1,017 & 1,392 \\
\hline
\end{tabular}

*Szignifikáns: $\mathrm{p}<0,05$

ÁOK = Általános Orvostudományi Kar; CI = konfidenciaintervallum; FOK = Fogorvostudományi Kar; WBI-5 = 5 tételes WHO Jóllét Kérdőív 
4. táblázat |A gyógyszerészi fakultás logisztikus regressziós eredménye

A gyógyszerészhallgatók (GYTK) változói

\begin{tabular}{|c|c|c|c|c|c|c|}
\hline \multirow[t]{2}{*}{ Változók } & \multirow[t]{2}{*}{ B } & \multirow[t]{2}{*}{ S.E. } & \multirow[t]{2}{*}{ Sig. } & \multirow[t]{2}{*}{$\operatorname{Exp}(B)$} & \multicolumn{2}{|c|}{$95 \% \mathrm{CI}$ for $\operatorname{EXP}(\mathrm{B})$} \\
\hline & & & & & Lower & Upper \\
\hline Perzisztencia & 0,771 & 0,390 & $0,048^{*}$ & 2,162 & 1,007 & 4,641 \\
\hline Hatalom mások felett & 1,211 & 0,527 & $0,022^{*}$ & 3,357 & 1,195 & 9,427 \\
\hline Vallásos hit & 1,852 & 0,657 & $0,005^{*}$ & 6,375 & 1,757 & 23,124 \\
\hline Internet: tantárggyal kapcsolatos anyagot tölt le közösségi oldalakról naponta & 0,285 & 0,167 & $0,068^{\#}$ & 1,330 & 0,959 & 1,845 \\
\hline A kapcsolatok fontossága miatt tanul & 0,873 & 0,324 & $0,007^{*}$ & 2,395 & 1,269 & 4,520 \\
\hline Hány \%-án vesz részt az óráinak & 0,996 & 0,559 & $0,075^{\#}$ & 2,708 & 0,905 & 8,103 \\
\hline A sport fontossága & 0,370 & 0,153 & $0,015^{*}$ & 1,448 & 1,073 & 1,953 \\
\hline WBI-5 & 0,266 & 0,146 & $0,058^{\#}$ & 1,305 & 0,981 & 1,738 \\
\hline Van olyan egyetemi társa, aki tanulási problémákban segít & 0,955 & 0,385 & $0,013^{*}$ & 2,600 & 1,223 & 5,527 \\
\hline Bizalom & 0,734 & 0,375 & $0,050^{\#}$ & 2,084 & 1,00 & 4,344 \\
\hline
\end{tabular}

*Szignifikáns: $\mathrm{p}<0,05$

\#Borderline szignifikancia

$\mathrm{CI}=$ konfidenciaintervallum; GYTK $=$ Gyógyszerésztudományi Kar; WBI-5 $=5$ tételes WHO Jóllét Kérdőív

5. táblázat $\mid$ A BSc-hallgatók logisztikus regressziós eredménye

Az egészségügyi szervező szakos, BSc-hallgatók (EKK) változói

\begin{tabular}{|c|c|c|c|c|c|c|}
\hline \multirow[t]{2}{*}{ Változók } & \multirow[t]{2}{*}{ B } & \multirow[t]{2}{*}{ S.E. } & \multirow[t]{2}{*}{ Sig. } & \multirow[t]{2}{*}{$\operatorname{Exp}(B)$} & \multicolumn{2}{|c|}{$95 \% \mathrm{CI}$ for $\operatorname{EXP}(\mathrm{B})$} \\
\hline & & & & & Lower & Upper \\
\hline Perzisztencia & 0,585 & 0,298 & $0,048 *$ & 1,794 & 1,010 & 3,219 \\
\hline Vallásos hit & 1,975 & 0,826 & $0,017^{*}$ & 7,205 & 1,429 & 36,341 \\
\hline A munkával kapcsolatos jövóbeli elvárások & 0,229 & 0,072 & 0,001 * & 1,258 & 1,093 & 1,448 \\
\hline Dolgozott-e valaha & 0,489 & 0,290 & $0,080^{\#}$ & 1,630 & 0,924 & 2,876 \\
\hline Egyetemi oktató hatása & 0,531 & 0,180 & $0,003^{*}$ & 1,700 & 1,194 & 2,421 \\
\hline Fontos ez a diploma, mert ez a képesítés elismert & 0,335 & 0,100 & 0,001 * & 1,398 & 1,150 & 1,699 \\
\hline Nem bátortalanít el, ha hibázom & $-0,808^{\#}$ & 0,275 & $0,003^{*}$ & 0,446 & 0,260 & 0,765 \\
\hline A sport fontossága & 0,392 & 0,185 & $0,034^{*}$ & 1,480 & 1,030 & 2,127 \\
\hline Hány \%-án vesz részt az óráinak & 0,778 & 0,462 & $0,070^{\#}$ & 2,177 & 0,880 & 5,385 \\
\hline Van olyan egyetemi társa, aki tanulási problémákban segít & 1,413 & 0,481 & $0,003 *$ & 4,108 & 1,602 & 10,535 \\
\hline A szülők végzettsége & $-0,903^{\#}$ & 0,384 & $0,019 *$ & 0,405 & 0,191 & 0,860 \\
\hline WBI-5 & 0,244 & 0,074 & $0,001 *$ & 1,276 & 1,104 & 1,475 \\
\hline Bizalom & 0,740 & 0,467 & $0,081^{\#}$ & 2,097 & 0,839 & 5,239 \\
\hline
\end{tabular}

* Szignifikáns: $\mathrm{p}<0,05$

\#A negatív B-érték azt jelenti, hogy ezek a prediktorok inkább csökkentik a hallgatói eredményességet

Bsc $=$ alapképzés; CI = konfidenciaintervallum; EKK = Egészségügyi Közszolgálati Kar; WBI-5 = az Egészségügyi Világszervezet 5 tételes jóllétkérdöíve

káns eltérés, a két kart összevontan (orvostanhallgatók) kezeltük. Karonként vizsgáltuk a hallgatók eredményességét befolyásoló magyarázó változókat, az eredményeket a 3. és 4. táblázatban helyeztük el. A GYTK esetében új változóként jelenik meg az előző karokhoz képest a „Kapcsolatok fontossága miatt tanul” szem- pont. A borderline szignifikáns változók hatása nem hanyagolható el a modell illeszkedése szempontjából, illetve ezek a változók itt is fontosak az eredményességet illetően (5. táblázat). A 6. táblázat a logisztikus regresszió által adott prediktív változók összefoglalását tartalmazza. 
6. táblázat |A karonkénti közös prediktor változók bemutatása

\begin{tabular}{|c|c|c|}
\hline \multicolumn{3}{|c|}{ Közös magyarázó változók bemutatása } \\
\hline ÁOK + FOK & GYTK & EKK \\
\hline Perzisztencia* & Perzisztencia* & Perzisztencia* \\
\hline $\begin{array}{l}\text { Hatalom mások } \\
\text { felett* }\end{array}$ & $\begin{array}{l}\text { Hatalom mások } \\
\text { felett* }^{*}\end{array}$ & - \\
\hline Vallásos hit* & Vallásos hit* & Vallásos hit* \\
\hline $\begin{array}{l}\text { Internet: tantárggyal } \\
\text { kapcsolatos anyagot } \\
\text { tölt le közösségi } \\
\text { oldalakról naponta* }\end{array}$ & $\begin{array}{l}\text { Internet: tantárggyal } \\
\text { kapcsolatos anyagot } \\
\text { tölt le közösségi } \\
\text { oldalakról naponta }\end{array}$ & - \\
\hline A sport fontossága * & A sport fontossága* & A sport fontossága * \\
\hline $\begin{array}{l}\text { Hány \%-án vesz részt } \\
\text { az óráinak* }\end{array}$ & $\begin{array}{l}\text { Hány \%-án vesz részt } \\
\text { az óráinak }{ }^{\#}\end{array}$ & $\begin{array}{l}\text { Hány \%-án vesz részt } \\
\text { az óráinak" }\end{array}$ \\
\hline WBI-5* & WBI-5 & WBI-5* \\
\hline $\begin{array}{l}\text { Van olyan egyetemi } \\
\text { társa, aki tanulási } \\
\text { problémákban segít* }\end{array}$ & $\begin{array}{l}\text { Van olyan egyetemi } \\
\text { társa, aki tanulási } \\
\text { problémákban segít* }\end{array}$ & $\begin{array}{l}\text { Van olyan egyetemi } \\
\text { társa, aki tanulási } \\
\text { problémákban segít* }\end{array}$ \\
\hline Bizalom* & Bizalom \# & Bizalom \# \\
\hline
\end{tabular}

ÁOK = Általános Orvostudományi Kar; EKK = Egészségügyi Közszolgálati Kar; FOK = Fogorvostudományi Kar; GYTK = Gyógyszerésztu dományi Kar; WBI-5 = 5 tételes WHO Jóllét Kérdőíív

*Szignifikáns: $\mathrm{p}<0,05$

\#Borderline szignifikancia

\section{A karonként eltéró prediktor változók bemutatása:}

ÁOK, FOK: Szülôii hatás a tanulásra*

GYTK: A kapcsolatok fontossága miatt tanul ${ }^{*}$

EKK:

- A munkával kapcsolatos jövőbeli elvárások* (lesz munkája)

- Dolgozott-e valaha\#

- Egyetemi oktató hatása*

- Fontos ez a diploma, mert ez a képesítés elismert*

- Nem bátortalanít el, ha hibázom*

- Szülők végzettsége*

*Szignifikáns: $p<0,05$

\#Borderline szignifikancia

\section{Megbeszélés}

Az újonc hallgatók körében - az eredményességet, sikerességet segítő jellemzőket keresve - a kérdőíves válaszadásban 156 férfi és 394 nő vett részt, és a négy kar között szignifikáns eltérés mutatkozik a nemek arányai között, a női hallgatók javára. A nők átlagéletkora 20,19 év, a férfiaké 20,37 év. Nincs lényeges eltérés a nemek életkora között, nem 18 év körül kezdik a felsőoktatást. $\mathrm{Ez}$ adódhat abból, hogy sokan nem rögtön érettségi után kezdik egyetemi tanulmányaikat, vagy azért, mert nem vették fel, vagy azért, mert még nem alakult ki, hogy merre szeretne továbbtanulni.

Ha már eldöntötte, és fel is vették a kiválasztott karra, akkor az eredményes tanulás a következő lépés. Az orvostanhallgatóknak - a nagy mennyiségű tananyag megtanulása miatt - a kitartás nagyon fontos, és ezt náluk segíti a szülők hatása, akikre jellemző, hogy felsőfokú végzettségük van, ezáltal tudják, milyen kihívások állnak a gyerekeik elött, s tudnak nekik segíteni. Az órák nagy százalékára való bejárás a hallgatói tudatosságot tükrözi, amiben az érdeklődés tükröződik, és amit érdemes az oktatóknak a további évek folyamán is fenntartani. A sportolás elősegíti a mentális egészség fennmaradását - az orvosi kar hallgatói az egyedüliek, akik ki is használják az egyetemi sportinfrastruktúrát. Az internet oktatásszempontú használata az oktatóktól elvárt, ezért természetes, hogy eredményességet segítő tényezőként szerepel. A fontosnak tartott vallásosság egyrészt megmagyarázza a segítő identitás kialakulását, másrészt olyan értékeket, normákat, magatartásmintákat alakít ki, amelyek a hallgatói eredményesség irányába hatnak. A hatalomvágy mások felett attitűdjének megjelenése a tanulmányok kezdetén a hivatástudat kialakulásának csírájaként értékelhető. A professzió sajátja, hogy a tanulmányi évek során, a szakmai tudás növekedésével, ez is egészséges mértékben növekedjen. Az egyetemi tanulótárs (barát) szükséges a tanulmányok során felmerült problémák könnyebb megoldásában, ezáltal is csökkentve a stresszhatásokat. A magánéletben is sok segítséget adhatnak egymásnak. A jólléti (well-being, WB) koncepció erkölcsi, emberi képesség, és - mint látjuk - sikerességi szempontból is megfogalmazódik a hallgatókban. Az orvostanhallgatók az általános bizalom meglétét érzik pozitív, eredményességet elősegítő jellemzőnek. Ez nagyon pozitív a tanulmányok legelején, hiszen erre alapul a személyi bizalom a későbbiekben.

A gyógyszerészhallgatók körében az eredményeséget segítő jellemzők nagyobb részben megegyeznek az orvostanhallgatók körében tapasztaltakkal. Ez a kar kisebb az orvosi karnál, könnyebben megismerhető, ez is oka lehet annak, hogy a hallgatók fontosnak tartják a bizalom meglétét mint eredményességi segítő tényezőt. Sajnos ők nem használják ki az infrastrukturális lehetőségeket, aminek komoly oka lehet, hogy „Budapest-szerte” tanulnak, sokat utaznak az órákra, így nem marad szabad idejük. Fontos, hogy a kapcsolat építése számukra meghatározó jellemző, hiszen ők a betegek, orvosok és gyógyszerészi asszisztensek kapcsolathálójában végzik majd a munkájukat. Természetesen az egyetemi tanulmányok alatti kapcsolatok felépítése és használata a gyógyszerészi identitás kialakulását is segíti. Megjegyezhetjük a kapcsolatok kialakításának fontosságát tárgyalva, hogy a nók kb. háromszor annyian járnak erre a karra, mint a férfiak.

A szülői végzettségek azt mutatják, hogy míg az orvosi karokon nagyon kevés számban vannak jelen az alapfokú végzettségű szülők, addig az egészségügyi szervezők- 
nél 50\%-os az arányuk, tehát ide be tudnak kerülni a gyerekeik. Ez a szak egyedinek számít abból a szempontból, hogy nagy hírü egyetemen az orvosi képzésben oktatók és a Múegyetem oktatói is részt vesznek a képzésükben, ami ezáltal magas színvonalú. A hallgatók elvárják az oktatói segítséget. A kitartás megéri, mert a megszerzett diploma elismert a munka világában. A hallgatói eredményességet - a hallgatói befektetés mértékétől függően - befolyásolhatja az intézményi tudásszerzés lehetőségének kihasználása, az akadémiai/tanulmányi normákkal való azonosulás, a munkavállalási hajlandóság és az önképzési hajlandóság. Az EKK (BSc)-hallgatók alacsony szinten használják ki a tudásszerzési lehetőségeket, ami származhat az alacsony szintú szülői végzettségből, a számukra ismeretlen világ kezdeti felfedezéséből. Nekik nagy munkatapasztalatuk van, és közöttük vannak a legtöbben, akik tovább szeretnének tanulni a diploma megszerzése után. Ez jelentheti azt is, hogy jelenlegi tanulmányukat hasznosnak tartva, a tanulással specializált tudásra akarnak szert tenni. Náluk is megtaláljuk az orvostanhallgatóknál felsorolt jellemzőket, de őket nagy munkatapasztalat jellemzi, egyetem mellett is dolgoznak. Nem bátortalanítja el őket, ha hibáznak. Ez nagyon fontos jellemző, ha meg is akarják szerezni a diplomát.

A karok besorolása az „eredményesebb” osztályba arra vezetett, hogy a FOK-hallgatók „eredményesebb” besorolása gyakoribb, mint a többi karon. Az láhatóvá vált, hogy a szülői végzettség növekedésével az eredményesebb hallgatók aránya is magasabb, de meghatározó különbség nincs. Szignifikáns a besorolás eredménye az órák látogatottsága szerint. Tehát ha az elsőéves hallgató látogatja az előadásokat, gyakorlatokat, azzal saját eredményességéhez, sikeréhez járul hozzá.

$\mathrm{Az}$ akadémiai „szigorúságon" túllépve, bevontuk a vizsgálatba a hallgatói jóllét, a kitartás, sportolás kérdését, és szignifikáns különbséget kaptunk a két eredményességi csoport között. A felsorolt változók mind az eredményességet segítik. A szülői odafigyelés, a tanulásban segítő kortárs megléte eredményesebbé teszik az elsőéves hallgatót. A hallgatói eredményességhez a napi internethasználat (tananyaggal kapcsolatos letöltés) hozzátartozik, mert az interneten elérhetővé tett tananyagra támaszkodva készülnek a számonkérésekre. Fordítva is beigazolódott a megállapítás, a kevesebb internethasználat gyengébb eredményességet hoz. A vallásos hit az eredményesebb hallgatók körében fontos. A „hatalom mások felett” fontossága magyarázható az oktató-hallgató viszonylatban érzékelt hatalmi viszonyokkal, és az egészségügyi pályán a szakértelem birtoklásával párhuzamosan alakul.

A hallgatók az egyetemi világ által biztosított infrastruktúrát különböző mértékben használják ki. Az étkezési helyek, a megfizethető kollégiumi hely, a sportolási lehetőségek, a könyvtár rendszeres használata elősegítheti az eredményes tanulmányi munkát. Van, akit gazdagabb infrastruktúrahasználat jellemez, van, aki szerényebben él a lehetőségekkel. Az eredményességet pozitív irányban befolyásolja, ha a hallgató kihasználja az egyetem által nyújtott infrastrukturális lehetőségeket, és akik ezt megteszik, azok jellemzően felsőfokú végzettségú szülők gyermekei. Az alapfokú végzettséggel rendelkező hallgatók egyáltalán nem használják ezeket a lehetőségeket. Ezért kell az oktatóknak, illetékes szakembereknek odafigyelni arra, hogy ne lehessen semmilyen akadálya ennek a hallgatók körében, bátrabban ismerkedjenek azzal, ami számukra ismeretlen (például az egyetemi könyvtár világa). Karonként nézve, az EKK és a GYTK használja ki a legkevésbé a lehetőségeket. A nagyvárosias településről érkezettek és a felsőfokú végzettségű szülők gyermekei eredményesebbek. A középfokú végzettségű és megyeszékhelyen lakó szülők gyerekei az átlagos/ gyengébb csoportba kerültek.

Szignifikáns kapcsolatot találtunk az általános bizalom és a „Kar” változó között. Az ÁOK esetében magas, az EKK esetében alacsony a bizalomérték. A vizsgált időpontban az eredményesség nem mutatott szignifikáns kapcsolatot az általános bizalommal.

\section{Következtetés}

A kérdőív adatainak segítségével a Semmelweis Egyetem négy karán tanuló hallgatók egy lehetséges eredményességi profiljának képe rajzolódott ki, a tanulmányaik megkezdésének időpontjában. A hallgatók szubjektív választása alapján azt láthattuk, hogy az orvostanhallgatók használják ki a legjobban az intézmény által biztosított tudáslehetőségeket, ami az érdeklődés jelenlétét mutatja, itt még láthatják az oktatók a „csillogó szemeket”. Az akadémiai norma elfogadása minden karon jelen van, még ha nem is a maximális pontszámot képviselve. Kiderült, hogy a hallgatók jelentős része dolgozik, anyagilag hozzájárul a tanulási költségekhez. A későbbi továbbtanulás - ami az élethosszig tartó tanuláshoz kapcsolódik - a legmarkánsabban az alapképzésben részt vevőknél jelentkezik, ami érthető törekvés, de minden karon tudatában vannak a hallgatók, hogy szükséges lesz fejlődniük a szakmájukban.

A 'Sikerességi index' („Átlagos/gyengébb”, illetve „Eredményesebb”) használatakor - a képzési struktúrában való elhelyezkedés szerint - a karok között nem mutatható ki lényeges eltérés.

A hallgatók társadalmi státuszából általában szokott adódni különbség, de ebben a felmérésben nincs szignifikáns különbség az eredményességi besorolásban. Megfigyelhető, hogy a szülői végzettség szintjének emelkedésével magasabb az eredményesebb hallgatók aránya. Érvényesülni látszik, hogy a magasabb végzettségű szülők gyerekei eredményesebben kezdenek, ami a hallgató hozott tőkebefektetése.

Az elsőéves hallgatók között elvégzett eredményességi, sikerességi vizsgálat azért fontos, mert a feltárt jegyek ismerete segítheti mind az oktatókat, mind a hallgatókat az egyetemi eredményes munkában. A vizsgálat során választ kaptunk arra, hogy a különböző karok ese- 
tén az eredményességet befolyásoló személyiségi jegyek közül vannak olyanok, amelyek kari jellemzők, illetve kirajzolódtak azok a jegyek, amelyek eltérnek más karoktól.

Nehéz definiálni, hogy a kapun belüliek között kik az eredményesek. Intézményenként, karonként, szakonként érdemes tartalommal megtölteni ezt a fogalmat [5].

Anyagi támogatás: A közlemény megírása anyagi támogatásban nem részesült. A kutatást a K 123847-es nyilvántartási számú támogatási szerződés alapján a Nemzeti Kutatási, Fejlesztési és Innovációs Hivatal - NKFIH támogatta.

Szerzői munkamegosztás: D. Sz. M. doktorandaként végezte a kérdő́ives felmérést, annak statisztikai feldolgozását és a cikk szövegezését. P. G. professzor asszony témavezetőként szakmai, mentori segítséget nyújtott, valamint segített a kézirat szövegezésében. Sz. M. statisztikai tanácsaival segítette a kézirat elkészítését. A cikk végleges változatát valamennyi szerző elolvasta és jóváhagyta.

Érdekeltségek: A szerzők kijelentik, hogy nincsenek érdekeltségeik.

\section{Irodalom}

[1] Szemerszki M. Characteristics of applicants in higher education. In: Szemerszki M. (ed.) Further education and selection from graduation to master's degree. [A felsőoktatásba jelentkezők jellemzői. In: Szemerszki M. (szerk.) Az érettségitől a mesterképzésig. Továbbtanulás és szelekció.] Oktatáskutató és Fejlesztő Intézet, Budapest, 2012; pp. 19-50. [Hungarian]

[2] Hassel S, Ridout N. An investigation of first-year students' and lecturers' expectations of university education. Front Psychol. 26 January, 2018. Available from: https://www.frontiersin.org/ articles/10.3389/fpsyg.2017.02218/full [accessed: June 18, 2019].

[3] Pusztai G. Student performance concepts and indicators in higher education research. In: Nagy P, Veroszta Zs. (eds.) Higher education research. [Hallgatói eredményességi koncepciók és mutatók a felsőoktatás-kutatásban. In: Nagy P, Veroszta Zs. (szerk.) A felsőoktatás kutatása.] Gondolat Könyvkiadó, Budapest, 2014. [Hungarian]

[4] Pusztai G. What is the concept of social capital in higher education research good for? In: Kozma T. (ed.) HERA Yearbook 2014. [Mire jó a társadalmi tôke koncepció a felsőoktatáskutatásban? In: Kozma T. (szerk.) HERA Évkönyv 2014.] HERA, Budapest, 2015. [Hungarian]

[5] Pusztai G. From invisible hand to friendly hands. [A láthatatlan kéztől a baráti kezekig.] Új Mandátum Kiadó, Budapest, 2011. [Hungarian]

[6] Pusztai G. Institutional impact and resources. In: Pusztai G, Bocsi V, Ceglédi T. (eds.) Added value of higher education. [Az intézményi hatás és forrásai. In: Pusztai G, Bocsi V, Ceglédi T. (szerk.) A felsőoktatás hozzáadott értéke.] Partium Könyvkiadó, Personal Problems Solutions, Új Mandátum Könyvkiadó, Nagyvárad-Budapest, 2016; pp. 112-136. [Hungarian]

[7] Hansen JB. Student performance and student growth as measure of success: an evaluator's perspective. Paper presented at annual meeting of the American Educational Research Association, New
Orleans, Louisiana, 2000. Available from: https://eric.ed. gov/?id=ED443876 [accessed: May 13, 2019].

[8] Astin AW. What matters in college: four critical years revisited. Jossey-Bass Publishers, San Francisco, CA, 1993.

[9] Müller H, Prinsloo P, Pleisis AD. Validating the profile of a successful first year accounting student. Meditari Account Res. 2007; 15: 19-33. Available from: https://gimmenotes.co.za/ wp-content/uploads/2016/12/FAC1502-Validating-the-profile-of-a-first-year-accounting-student.pdf [accessed: January 12, 2019].

[10] Tinto V. Leaving college: rethinking the causes and cures for student attrition. University of Chicago Press, Chicago, IL, 1987.

[11] Pascarella ET, Terenzini PT. How college affects students: findings and insights from twenty years of research. Jossey Bass Publishers, San Francisco, CA, 1991

[12] Zhou Y, Zhao Z., Li L, et al. Predictors of first-year GPA of medical students: a longitudinal study of 1285 matriculates in China. BMC Med Educ. 2014; 14: 87. Available from: https:// www.ncbi.nlm.nih.gov/pmc/articles/PMC4004455/ [accessed: July 5, 2019].

[13] Mills C, Heyworth J, Rosenwax L, et al. Factors associated with the academic success of first year health science students. Adv Health Sci Educ Theory Pract. 2009; 14: 205-217.

[14] Frischenschlager O, Haidinger G, Mitterauer L. Factors associated with academic success at Vienna Medical School: prospective survey. Croatian Med J. 2007; 46: 58-65.

[15] Coleman JS. Social capital in the creation of human capital. Am J Soc. 1988; 94: S95-S120. Available from: https://www.econ. msu.ru/cmt2/lib/c/477/File/Social\%20Capital\%20in\%20 the $\% 20$ Creation $\% 20 \mathrm{of} \% 20 \mathrm{Human} \% 20 \mathrm{Capital} . p d f \quad$ [accessed: July 5,2019$]$.

[16] Camara WJ, Kimmel EW. (eds.) Choosing students; Higher education admissions tools for the 21 st century. Lawrence Erlbaum Associates Publishers, London, 2005.

[17] Dinyáné SzM, Pusztai G. Investigation of persistence value as a study protection factor among health care organizer students. Eur J Mental Health 2017; 12: 135-151. Available from: http://semmelweis.hu/ejmh/2017/12/10/investigation-ofpersistence-value/ [accessed: July 8,2019$]$.

[18] Szemerszki M. Dimensions and background factors of student outcomes. In: Szemerszki M. (ed.) Effectiveness in education. Dimensions and approaches. [A tanulói eredményeség dimenziói és háttértényezői. In: Szemerszki M. (szerk.) Eredményesség az oktatásban. Dimenziók és megközelítések.] Oktatáskutató és Fejlesztő Intézet, Budapest, 2015; pp. 52-91. Available from: http://ofi.hu/sites/default/files/attachments/ $1505765_{-}$ eredmenyesseg_az_oktatasban_beliv.pdf [accessed: July 5 . 2019]. [Hungarian]

[19] Albert F, Dávid B. Man's friend. The sociology of friendship. [Embert barátjáról. A barátság szociológiája.] Századvég Kiadó, Budapest, 2007. [Hungarian]

[20] Bandura A. Self-efficacy: the exercise of control. Freeman \& Co., New York, NY, 1997.

[21] Dinyáné SzM, Pusztai G. Use of the short (5-item) version of the WHO well-being questionnaire in first year students of Semmelweis University. [Az Egészségügyi Világszervezet öttételes jól-lét kérdő́ivének vizsgálata a Semmelweis Egyetem elsóéves hallgatóinak körében.] Orv Hetil. 2016; 157: 1762-1768. [Hungarian]

[22] Pacsuta I. Comparative qualitative assessment of students in higher education. [A felsőoktatásban részt vevő hallgatók összehasonlító kvalitatív értékvizsgálata.] Erdélyi Társadalom 2017; 15: 27-39. [Hungarian]

[23] Bocsi V. Harmony or dissonance? Exploring modern leisure in the world of campus. In: Dusa Á, Kovács K, Márkus Zs, et al. (eds.) University life situations: youth sociology studies. [Harmónia vagy disszonancia? A modern szabadidő vizsgálata a campusok világában. In: Dusa Á, Kovács K, Márkus Zs, et al. 
(szerk.) Egyetemi élethelyzetek: Ifjúságszociológiai tanulmányok.] Debreceni Egyetem, 2012; 195-208. [Hungarian]

[24] Pőcze G. Influence, power, participation In: Mihály O. (ed.) School and pluralism. [Befolyásolás, hatalom, részvétel. In: Mihály O. (szerk.) Iskola és pluralizmus.] Edukáció, Budapest, 1989; pp. 31-44. [Hungarian]

[25] Tomka M. Religious situation - 2009. In: Rosta G, Tomka M. (eds.) What do Hungarians value? Hungarian results of the European Values Survey 2008. [Vallási helyzetkép - 2009. In: Rosta G, Tomka M. (szerk.) Mit értékelnek a magyarok? Az Európai Értékrend Vizsgálat 2008. évi magyar eredményei.] Faludi Ferenc Akadémia, Budapest; 2010; pp. 401-425. [Hungarian]

[26] Rosta G. Faith and religious practice. In: Székely L. (ed.) Hungarian Youth 2012. [Hit és vallásgyakorlat. In: Székely L. (szerk.) Magyar Ifjúság 2012.] Kutatópont, Budapest, 2013; pp. 316330. [Hungarian]

[27] Tomcsányi T, Fodor L. Helping relationship, helping syndrome, helping identity. In: Pálhegyi F. (ed.) Psychological basics and techniques of personal conversation. [Segítő kapcsolat, segítő szindróma, segítő identitás. In: Pálhegyi F. (szerk.) A személyes beszélgetés pszichológiai alapjai és technikája.] Károli Gáspár Református Egyetem, Budapest, 1995. [Hungarian]

[28] Pusztai G. The role of higher education in preparing students for work. In: Kun AI, Polónyi I. (eds.) Situation in the Northern Great Plain Region: training and the labor market. [A felsőoktatás munkára felkészító szerepe a hallgatók értelmezésében. In: Kun
AI, Polónyi I. (szerk.) Észak-alföldi régió helyzete: képzés és munkaerópiac.] Új Mandátum Kiadó, Budapest, 2013; pp. 9-29. [Hungarian]

[29] Cuseo J. Student success: definition, outcomes, principles and practices. The following material has been excerpted from "The Big Picture," a column appearing in Esource for College Transitions (Electronic Newsletter), published by the National Resource Center for the First-Year Experience \& Students in Transition, University of South Carolina, 2015. Available from: https://www2 indstate.edu/studentsuccess/pdf/Defining\%20 Student $\% 20$ Success.pdf [accessed: December 25, 2018].

[30] Coleman JS. Social theory, social research and a theory of action. Am J Sociol. 1986; 91: 1309-1335.

[31] Kuh GD, Cruce TyM, Shoup R, et al. Unmasking the effects of student engagement on first-year college grades and persistence. Published by The Ohio State University Press, J Higher Education 2008; 79: 540-563.

[32] Strange CC. Dynamics of campus environments. In: Komives SR, Woodard DB. (eds.) Student services: handbook for profession. Jossey Bass Publishers, San Francisco, CA, 2003; pp. 297316.

(Dinyáné Szabó Marianna, Budapest, Tamási Áron u. 18., 1124 e-mail: dinyane.mariann@public.semmelweis-univ.hu)

\section{"Tamdiu discendum est, quamdiu vivas." (Míg élsz, egyre tanulj, és soha abba ne hagyd!)}

A cikk a Creative Commons Attribution 4.0 International License (https://creativecommons.org/licenses/by/4.0/) feltételei szerint publikált Open Access közlemény,

melynek szellemében a cikk bármilyen médiumban szabadon felhasználható, megosztható és újraközölhető, feltéve, hogy az eredeti szerző és a közlés helye, illetve a CC License linkje és az esetlegesen végrehajtott módosítások feltüntetésre kerülnek. (SID_1) 